Available online at www.refaad.com

VMPH 2(1); 2021: 23-24

Letter to the Editor

Veterinary Medicine and Public Health Journal (VMPH)

Journal Homepage: https://www.refaad.com/views/vmph/home.aspx

www.refaad.com

ISSN : 2707-7195(Online) 2707-7187(Print)

\title{
COVID-19: what are the precautionary measures that you do if you travel to a country with the epidemic?
}

\author{
Ali A. Dawood*a

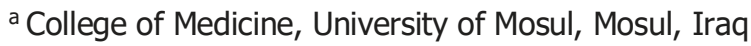

* Corresponding author: Ali A. Dawood. Email: aad@uomosul.edu.iq

How to cite this article: Dawood, A. A., COVID-19: what are the precautionary measures that you do if you travel to a country with the epidemic?. Veterinary Medicine and Public Health Journal 2(1); 2021: 23-24.

DOI: https://doi.org/10.31559/vmph2021.2.1.4 Received Date: 18/8/2020 Revised Date: 2/9/2020 Accepted Date: 15/9/2020

Several countries have reported a sizeable increase in the number of cases of the COVID-19 between intimate partners particularly during the lockdown phase of the pandemic, such as Canada, China, the USA, and most EU countries. If you think to travel to one of the epidemic countries, you must take into consideration some precautionary measures before departure.

1- Listening to home news: Care of rises in newly infected cases and consider how the local verdict addresses the issues. If you have on the trip and no trust that the government can restrain the virus effectively, you have to cancel your trip.

2- Follow the foreign office: They ought to have at the latest information about the prevalence disease and how can give counsel accordingly.

3- Monitor health daily: For example, if you have suffered from a weak immune system, long-term conditions of chronic diseases such as heart failure, lung or renal diseases, any types of cancers, or diabetes, you may likely develop severe symptoms if you are exposed to infection. Therefore, canceling the trip is a better option to reduce the exposure rate.

4- Delaying the flight reservation until the last moments: It is better to delay pre-booking flights in advance. Follow the latest news and search for deals at the last minute will make you feel more in control and less worried.

5- Put plan for all probabilities: You have to be aware that airlines may prevent you from boarding the plane if you are unhealthy. Also, you have to care about which country you arrive if it can handle the sudden wave of infected cases to preserve your health when you are put in quarantine.

At a moment, if you plan traveling within the next months, your insurance is out of covering any annulment. You may attempt rebooking, which likely demands more fee.

There is proof that presented perfect hygiene might help prohibit infection. Substantially, the attention propels to exercise is a common sense. Here are some useful tips:

1- Be more aware and careful of your circumference: For example, if you are in a public venue, with a group of people gathering closer or you have to travel by public transport, consider your actions and what you handle. Railway, bus, and subway services are bad enough for bacterial and viral contamination. Therefore, if you have any suspicion, you have to wear a mask and use hand sanitizer until you arrive at your destination.

2- Washing your hands repeatedly with soap and detergents after coughing, sneezing, or blowing nose and also after going out from the toilet specifically in public. Scrubbing fingers with detergents should be well taken at least 20 seconds. If you have lots of moves daily, you ought to use sanitizer spry or moisturizing hand wipes.

3- Avoid touching $\mathrm{T}$ region in your face: $\mathrm{T}$ region includes eyes, nose, and mouth which viruses can transmit by contaminated hands that pick up them.

4- Preserve social distance: World Health Organization recommends people to maintain a distance away from infected people at least 3 feet, although the last study revealed that the virus can be transmitted through coughing and sneezing droplets for a distance of up to five meters. If you stand close to an infected person, you may pick up the virus through breathing infected droplets.

5- Covering mouth when sneezing or coughing: Using dry tissue during sneezing and coughing is essential to reduce the prevalence of the virus and then dispose of it properly. Also, it is essential to use 
face masks for both an infected and a healthy person to minimize the spread of infected aerosols $[1,2,3]$.

\section{Advice:}

Most countries around the world have suspended granting entry visas or denied entry to visitors from the endemic nations. If you are unable to obtain sufficient information about the country you intend to travel to, you must plan many times for any eventualities, including what you will counter if the flight is canceled, you are stranded in a foreign land. Finally, perhaps when you arrive at your destination, the authorities may put you in quarantine for 14 days.

Acknowledgments: The author thanks the University of Mosul for documenting this work.

Funding: self-supporting.

Conflict of interest: There is no conflict of interest.

\section{References}

[1] Government of Canada. Coronavirus disease (COVID19): Travel restrictions, exemptions, and advice. (2020), $\quad$ https://www.canada.ca/en/publichealth/services/diseases/2019-novel-coronavirusinfection/latest-travel-health-advice.html.

[2] World Travel Guide: Can you travel safely when Coronavirus (COVID-19) is spreading fast? (2020), https://www.worldtravelguide.net/features/feature/canyou-travel-safely-when-coronavirus-covid-19-is-spreadingfast/.

[3] Wisconsin Department of Health Services. COVID-19: Travel. (2020), https://www.dhs.wisconsin.gov/covid19/travel.htm. 